SVETLANA ČIČEVIĆ, Ph.D.

E-mail: s.cicevic@sf.bg.ac.rs

VLADAN TUBIĆ, Ph.D.

E-mail : vladan@sf.bg.ac.rs

University of Belgrade,

Faculty of Transport and Traffic Engineering

Vojvode Stepe 305, 11000 Belgrade, Serbia

MILKICA NEŠIĆ, Ph.D.

E-mail : milkica@medfak.ni.ac.rs

University of Niš, Faculty of Medicine

Bulevar dr Zorana Đinđića 81, 18000 Niš, Serbia

MARJANA ČUBRANIĆ-DOBRODOLAC, M.Sc.

E-mail : marjana@sf.bg.ac.rs

University of Belgrade,

Faculty of Transport and Traffic Engineering

Vojvode Stepe 305, 11000 Belgrade, Serbia
Safety and Security in Traffic

Review

Accepted: June 14, 2010

Approved: May 17, 2011

\title{
YOUNG DRIVERS PERCEPTUAL LEARNING STYLES PREFERENCES AND TRAFFIC ACCIDENTS
}

\begin{abstract}
Young drivers are over-represented in crash and fatality statistics. One way of dealing with this problem is to achieve primary prevention through driver education and training. Factors of traffic accidents related to gender, age, driving experience, and self-assessments of safety and their relationship to perceptual learning styles (LS) preferences have been analyzed in this study. The results show that auditory is the most prominent LS. Drivers in general, as well as drivers without traffic accidents favour visual and tactile LS. Both inexperienced and highly experienced drivers show relatively high preference of kinaesthetic style. Yet, taking into account driving experience we could see that the role of kinaesthetic LS is reduced, since individual LS has become more important. Based on the results of this study it can be concluded that a multivariate and multistage approach to driver education, taking into account differences in LS preferences, would be highly beneficial for traffic safety.
\end{abstract}

\section{KEY WORDS}

young drivers, traffic accidents, perceptual learning styles preferences, self-assessment, driving experience, drivers' education

\section{INTRODUCTION}

Traffic fatalities and injuries among young drivers as result of road crashes constitute a serious public health problem and lead to substantial costs to society, not only in Europe, but in all parts of the world. This problem is especially pronounced in the age group of 15-29, in which traffic crashes are the lead- ing cause of death, and they account for $35 \%$ of all fatalities among young drivers [1].

Data from a number of different countries show that male drivers are involved in fatal road crashes three times more than female drivers in the same age group. To further illustrate the extent of the problem, it can be mentioned that during the years 1994-2005, 19\% of all those who were killed and $21 \%$ of those who were severely injured in road traffic crashes involving private vehicles were young novice drivers [2]. Typically young men are overrepresented in alcohol-related crashes, usually in combination with high speed, night-time driving, and the presence of passengers [3].

Many reviews have revealed that the lack of experience is one of the primary factors contributing to crash involvement among novice drivers [4]; the findings of many studies indicate that experience is more important than age when trying to explain why young drivers have high crash rates during early licensure [5]. Therefore, it is important that aspiring drivers are given the opportunity to gain as much experience as possible during the learning period, before they get a license. A driver's mental workload, visual search skills, and capacity for hazard perception are to a large extent connected with driving experience. These factors have been shown to be problematic for learners and novice drivers [6]. The more experienced a driver the easier it is for them to recognize and interpret different traffic situations, and on the basis of that develop "mental models" that can facilitate processing of the information and use of the available mental resources. Many 
investigations have shown that overconfidence is a real problem among novice drivers [7, 8, 9]. Whether adjusted for exposure or not, the high crash fatality and injury rates of young, male novice drivers represent a major public health issue.

The reasons why age, gender and experience combine so destructively in some young people on the road, and why some young people are more risk prone than others are highly complex. The great majority of young driver crashes are attributable to inexperience: errors in attention, visual search, speed relative to conditions, hazard recognition and emergency manoeuvres. Very few crashes could be attributed to intentional risk-taking behaviours, such as excessive speeds. Reducing the number of young, novice driver crashes and fatalities will require a focused and coordinated approach, involving education, training, licensing, enforcement, communication and the selective use of technology, in combination with other road safety measures. Training should focus on creating drivers who are safe, and not just technically competent, meaning that there should be increased focus on self-assessment and understanding of the factors that increase risk, including the context in which driving is undertaken. Essential to this is a training process that engages novice drivers personally and emotionally, increasing their awareness of their own limitations and of the dangers inherent to driving. In this way, driver training should promote the view of driver behaviour as a multi-level task. This hierarchical view of driving behaviour, while having its origins in a Finnish research, is now broadly acknowledged throughout Europe as being a useful starting point for driver education; widely known as the EU GADGET Matrix $[10,11]$. The fourth level in that matrix refers to the goals for life and skills for living, which relates to the importance of cars and driving for personal development and the driver's skills for self-control. The driver can influence the demands of the driving through behavioural choices. Ideally, the demands should match the driving ability. This is a function of regulation within the continuous driving process. Self-assessment is supposed to play a role in this regulation process [12]. Groeger and Brady [13] have found a positive association between selfassessment and driving experience. The idea is that the driver education should comprise all these levels. The GDE-framework can be used as the basis for the evaluation of specific driver education methods and also as basis for developing new ideas.

Young drivers are especially prone to overestimating their own driving ability compared with more experienced drivers. In driver training an explicit learning objective is to develop among learners a self-critical view of their own driving abilities [14]. Hence, it is of current interest to examine the association between driver training and self-assessment. This may support the view that unrealistic self-assessment may be one reason behind young drivers' relatively high accident record. However, research regarding the relationship between age, gender and self-assessment has reported mixed results $[15,16,17,18]$. Some studies have shown the association between age and selfevaluation to be moderated by driving experience [2, 19]. The content of self-evaluation is an important tool in driver training and also in development of driving skills after training. The research on development of expertise has shown that meta-cognitive skills and reflective thinking are essential characteristics of an expert [20, 21, 22]. Thus, training of self-evaluative skills should also be included in the training; they do not develop automatically. Abilities for self-evaluation are also expected to have relevance in driving behaviour. Educational methods that might be appropriate to increasing driver's skills for self-evaluation are improved feedback during training, self-assessment tools like questionnaires and scales, discussions with other youngsters about personal experiences and evaluations made by instructors or examiners. Skills for selfassessment as well as driver attitudes and individual needs, which can be considered as part of the highest levels in the hierarchy that are presented in the GDE framework have been referred to by Lynam and Twisk [4] as the most promising aspects for finding improvement in driver training. The evaluation of the existing driver education methods, as well as defining new goals and new methods should not only be based on empirical results but also on a conceptual analysis. A traditional criterion for a well-functioning driver training or driver improvement has been the number of violations and the number of accidents after training. Many of the new trends in the field of traffic safety are taking into consideration how people use their cognitive resources.

In order to find improvement measures for the traffic system itself and traffic characteristics, and gaining information and new ideas for safer traffic, research is aimed at component factors such as the driver, the vehicle and the traffic environment, with the emphasis on human factors $[23,24]$. Since society is responsible for the licensing system, which is supposed to produce safe drivers, a vital aspect of work in the area of public health is to modify the process of licensing. One way of dealing with the problems of young drivers is to achieve primary prevention through driver training. Education could be described as being based on three cornerstones - its goals, its content/process, and the tests - which should form one harmonized entity. However, such harmonization requires involvement of well educated professional driving instructors and driving examiners that together have the necessary knowledge, competence, and teaching skills to fulfil and cover all aspects of the driver training $[6,25]$.

We must discover what teaching methods are most appropriate and what combination of educational aids 
is best for each area of interest. Thus, developing comprehensive driver education requires an understanding not only of traffic safety but also of how young people learn. Young drivers vary greatly in their learning capacity, learning style, maturity, and risk-taking behaviour. Driver education and behind-the-wheel training need to accommodate those who learn visually, those who learn by listening, and those who learn by doing. A multivariate approach to teaching and learning can reach the maximum number of learners and help them learn to drive safely.

\section{LITERATURE REVIEW ON LEARNING STYLES}

Researchers have defined learning styles (LS) in different ways; for example, as natural, habitual, and preferred way(s) of absorbing, processing, and retaining new information and skills [26] or as cognitive, affective, and physiological traits that serve as relatively stable indicators of how learners perceive, interact with, and respond to learning environments [27]. They represent consistent pattern of behaviour and performance by which an individual approaches educational experiences. LS are derived from cultural socialization and individual personality as well as from the broader influence of human development. A preferential mode, through which a subject likes to master learning, solve problems, thinks or simply reacts in a pedagogical situation, should also serve as usable specification of LS. LS could also be defined as the complex manner in which, and conditions under which, learners most efficiently and most effectively perceive, process, store, and recall what they are attempting to learn; or an individual's characteristic way of processing information feeling, and behaving in learning situations; or as the preference or predisposition of an individual to perceive and process information in a particular way or combination of ways. LS are broadly described as cognitive, affective, and physiological traits that are relatively stable indicators of how learners perceive, interact with, and respond to the learning environment [26].

An extensive body of research has established that the majority of people learn most effectively with one of the three modalities and tend to miss or ignore information presented in either of the other two. Visual learners remember best what they see: pictures, diagrams, flowcharts, timelines, films, demonstrations. Auditory learners remember much of what they hear and more of what they hear and then say. They get a lot out of discussion, prefer verbal explanation to visual demonstration, and learn effectively by explaining things to others. Tactile learners like to touch and prefer hands-on activities (e.g. building models, doing laboratory experiments). Kinaesthetic learners like ex- periential learning, and prefer physical activities (e.g. field trips, role-play, and drama). These learners learn best when they are physically involved in the experience, so they remember new information if they are actively involved in activities with the teacher. Individual learners like to work alone and prefer self-directed study, independent reading and computer work, while Group learners like group interaction, and prefer social activities.

Although the diverse styles in which students learn are numerous, the inclusion of a relatively small number of techniques in an instructor's repertoire should be sufficient to meet the needs of most or all of the students in any class. In the mid- to late 1970s, paradigms began to be developed to identify the more external, applied modes of LS. Research by Dunn and Dunn resulted in The Learning Style Inventory, a self-reporting questionnaire that enables public school students to identify their LS preferences. Among the 21 identified LS have reported on perceptual LS, a term that describes the variations among learners in using one or more senses to understand, organize, and retain experience [28]. They found that only $20-30 \%$ of school age children appear to be auditory learners, $40 \%$ are visual, and that the remaining $30-40 \%$ are tactile/kinaesthetic, visual/tactile, or some other combination. Graduate students indicated a significantly greater preference for visual and tactile learning than undergraduates; undergraduates were significantly more auditory than graduates. Males preferred visual and tactile learning significantly more than females. Visual learning was selected as major LS only by students in hard sciences; surprisingly, humanities majors were the least oriented toward visual learning [29]. Students in four major fields preferred auditory as major LS: computer science, hard sciences, business, and medicine. The majority of the students (94\%) demonstrated the use of more than one major preferred LS.

Research has also suggested a link between LS and language background. According to Decapua and Wintergerst [30], Chinese and Vietnamese speakers preferred visual learning, while Reid [31] found that Spanish speakers preferred kinaesthetic and tactile LS. Dorsey and Pierson [32] conclude that age and prior work experience influence LS, and their data indicate that the adults, especially after the age of 33, learn better by doing (kinaesthetic learning). Both teachers and students involved in identifying and using information on LS should proceed with caution and be aware that no single diagnostic instrument can solve all the learning problems. Nevertheless, students learn better and more quickly if the teaching methods used match their preferred learning styles. As learning improves, self esteem improves, too. This has further positive effect on learning.

The approach and conclusions regarding the relationship between driver training and self-assessment 
are entirely identical to the outcomes of research in the field of study of LS. Increased safety and reduction of accidents are essential components of training drivers. For this reason, the research undertaken upon LS preferences of young drivers will be presented in this paper.

\section{CURRENT STUDY}

\subsection{Methodology}

Perceptual Learning-Style Preference Questionnaire (PLSPQ) by Joy Reid was used in this study. It consists of 30 randomly ordered statements for the six LS preferences to be measured: visual, auditory, kinaesthetic, tactile, group learning, and individual learning. Survey participants respond on the basis of a five-point Likert scale, ranging from strongly agree to strongly disagree. We chose to use the PLSPQ because it had been previously normed on high, intermediate and advanced ESL classes by Reid [32]. The PLSPQ was also one of the only three known normed survey instruments in this field, the authors of which permit these instruments to be used in replication studies. This instrument takes into account the sensory modality, which is, on the other hand, particularly important because driving skills largely depend on the sensory capacities of drivers which show increasing contribution in driving conditions which is characterized by the implementation of new technologies in the vehicle cabin when information presentation through different sensory modalities is necessary, in order to avoid overloading of the senses of sight. PLSPQ was neither long nor time-consuming to complete. In addition, the PLSPQ had pre-established cut-off scores for major, minor, and negligible LS categories. Preference means for each set of variables were classified into three ranges: major, minor, and negative LS preferences. Minor LS indicate areas where someone can function well as a learner. Usually, a very successful learner can learn in several different ways. Negligible LS often indicates that someone may have difficulty. Examples of the statements in the questionnaire are: I learn more when I can make a model of something; When I study alone, I remember things better; When the teacher tells me the instructions I understand better; etc. Subjects' answers could imply that they strongly agree (SA) or agree (A) with the statements (there are 5 questions for each learning category in the questionnaire) for each of the LS which will be categorized as major. Each question has a numerical value. For example, SA for any question receives number 5 . When the numerical value was assigned to the corresponding LS statement, the numbers were added to obtain a total score and then it was multiplied by 2 determining the major, minor or negligible LS. After that, all the results were analyzed to categorize them with respect to the aforementioned LS preferences. According to the scoring procedure, it shows what percentage of respondents have a total score for each of the LS, higher than 38 (for major LS). More than one LS could have the same score, i.e., the preference among the respondents in percents, which indicate the use of more than one major preferred LS.

\subsection{Participants}

The sample consisted of 83 drivers, 27 females and 56 males, and a small control group of 20 students studying at the Faculty of Traffic and Transport Engineering, University of Belgrade, who were without driving license. The students' age ranged from 19 to 31 , with a mean age of 22.41 . In our sample $21.7 \%$ of drivers were involved in traffic accidents, $2 / 3$ of them were males, and $1 / 3$ females. The participants were asked to volunteer to complete the questionnaire. The responses were statistically analyzed to identify the prevalence of LS and the relationship of LS preferences to such variables as gender, driving experience, self-assessment of safety, and number of traffic accidents.

\section{RESULTS}

In this paper, the descriptive statistics was calculated for all questionnaire data, and comparisons made regarding the abovementioned variables. Only major LS preferences (the mean scores which fall into the major category) will be represented. Major LS indicate that an individual could function well as a learner. The results show that the auditory is the most prominent LS in all groups, and characteristic for the drivers. Similar holds for drivers without traffic accidents. We could see that the kinaesthetic and the auditory LS are dominant in control group, and group LS appears in $25 \%$ of cases. The visual and the tactile, and to some extent, individual LS presence, with $50 \%$ of group LS preferences, were characteristic for drivers involved in traffic accidents (Table 1). The values in Table 1 represent the percentage of subjects in each group who chose a certain LS as their major LS. Subjects are able to employ multiple LS as major, according to the abovementioned scoring procedure.

The main difference between controls and drivers with traffic accidents is reflected in the percent of cases where kinaesthetic LS are dominant $(60 \%$ and $27.8 \%$ respectively).

Gender differences in LS preferences. Generally, gender differences are pronounced for the presence of individual LS, females are less individual in their preferences than males. All other LS, except visual, are more prominent for females. Males and females 
Table 1 - Distribution of major learning style preferences among drivers and non-drivers

\begin{tabular}{|l|c|c|c|c|c|c||}
\hline \% of participants' dominant LS & Visual & Tactile & Auditory & Kinaesthetic & Group & Individual \\
\hline \hline Control group & 25 & 50 & 75 & 60 & 25 & 50 \\
\hline Drivers & 41.8 & 41.8 & 60.8 & 35.4 & 34.2 & 39.2 \\
\hline Drivers without accidents & 41.5 & 41.5 & 55.4 & 38.5 & 20 & 35.4 \\
\hline Drivers with accidents & 33.3 & 38.9 & 72.2 & 27.8 & 50 & 44.4 \\
\hline \hline
\end{tabular}

Table 2 - Distribution of major learning style preferences with respect to driving experience

\begin{tabular}{||c|c|c|c|c|c|c||}
\hline $\begin{array}{c}\text { \% of participants' major } \\
\text { LS /Driving experience }\end{array}$ & Visual & Tactile & Auditory & Kinaesthetic & Group & Individual \\
\hline \hline$<2$ years & 44.9 & 40.8 & 59.2 & 44.9 & 32.6 & 34.7 \\
\hline 2 - 4 years & 38.5 & 42.3 & 65.4 & 19.2 & 38.5 & 50 \\
\hline
\end{tabular}

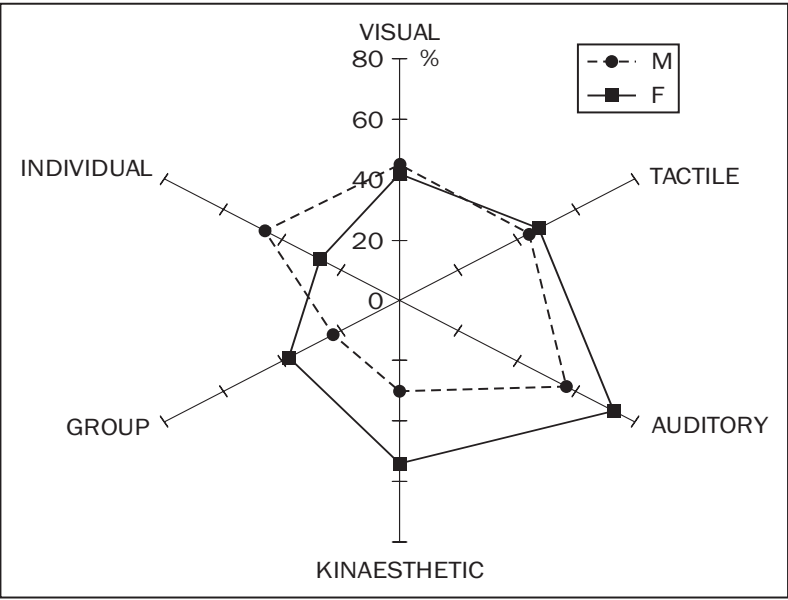

Figure 1 - Gender differences in major learning style preferences

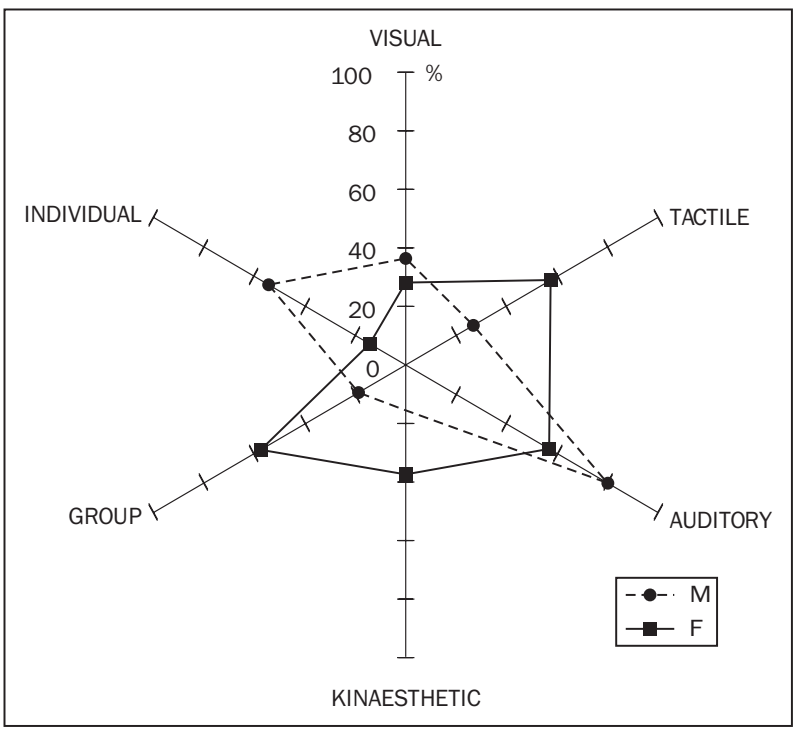

Figure 2 - Gender differences in major learning style preferences of drivers

show most similarity in tactile LS preferences (Figure 1). Quite different situation is noticed for the group of drivers. The most prominent LS in male drivers are auditory and individual, while kinaesthetic and group LS are present in fewer cases. Tactile, auditory and group LS are of equal prominence for females (Figure 2). Auditory (and tactile) LS are more expressive in group with more than two years of driving experience. At the same time, kinaesthetic LS is present only in 19\% of subjects. They seem to be more individual learners than drivers with less experience. Visual, tactile and kinaesthetic LS account for 40-45\% in the group with $<2$ years of driving experience (Table 2 ).

Considering the most frequent combination of LS within the group of drivers, some gender differences appear. The Auditory-group combination is present in $66.7 \%$ cases, tactile-auditory and tactile-kinaesthetic in $50 \%$, and visual-tactile, as well as visual-kinaesthetic, in $33.3 \%$ of females. Male drivers show lesser number of combinations than females. The most prominent combination is auditory-individual (57.1\%), then, visual-auditory and visual-group, both in $14.3 \%$ cases.

Driving experience and LS preferences. When considering driving experience per kilometres travelled, the distribution of major LS appear to be different. For the majority of drivers, in the group with the least driving experience, the auditory is still the dominant LS, followed by kinaesthetic, visual and individual, while group LS was preferred by the minority of drivers. Within the group of drivers with up to $25,000 \mathrm{~km}$ travelled, the LS distribution showed greater uniformity as related to both group with higher and group with lower driving experience, although auditory style is still dominant. Also, preferences to individual and tactile LS are pronounced. The remaining LS were preferred by the drivers to equal extent (35\%). Auditory LS is dominant for the most experienced drivers (up to $100,000 \mathrm{~km}$ driven), and tactile, group and kinaesthetic follow (with the last two preferred by $47.06 \%$ of drivers). The fact that visual LS was less preferred within this group is somewhat surprising having in mind that driving is primarily a visual task. The contribution of visual LS decreases with the number of kilometres travelled. On the contrary, the share of tactile and group LS increases with the driving experience. Auditory LS dominates 
among the highest, and the least experienced drivers. With the number of kilometres travelled individual LS showed the smallest range of variation. Inexperienced drivers show relatively high preference of kinaesthetic style, and with driving experience this preference decreased, whereas within the group with great number of kilometres travelled, the preference towards kinaesthetic LS increased again (Figure 3).

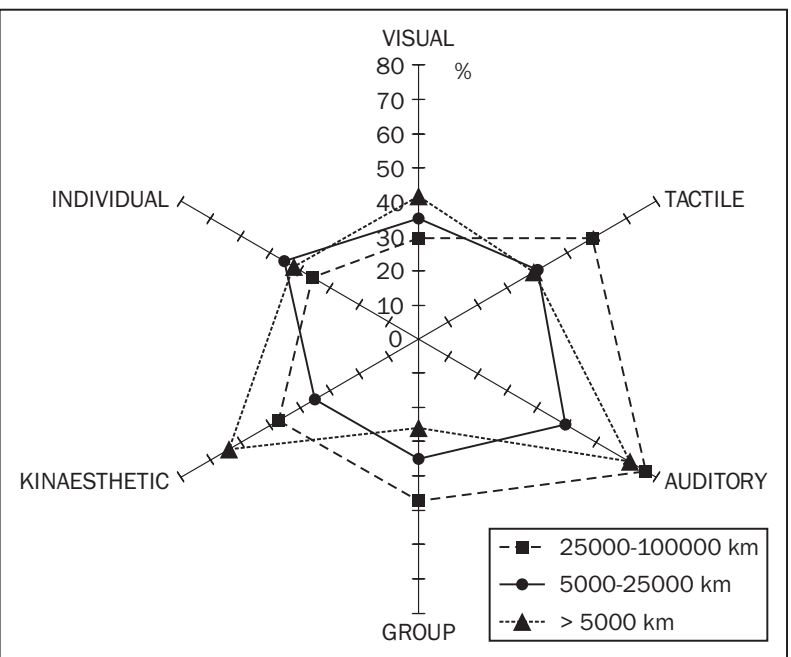

Figure 3 - Distribution of major learning style preferences with respect to driving experience

Self-assessment of safety and LS preferences. The drivers who perceived themselves as safe preferred auditory LS in $62 \%$ of cases, while kinaesthetic and group LS are less preferred. The distribution of LS preferences is more uniform within the group of drivers who evaluated themselves as unsafe. Auditory, tactile and kinesthetic LS, namely, are preferred as dominant in $50 \%$ of drivers. Group, individual and visual LS were preferred as dominant to the same extent (37.5\%). The largest difference between two groups was observed for visual LS, preferred by a higher percentage of drivers who consider themselves to be safe. Similar holds for kinaesthetic LS which was more preferred by the drivers who tend to perceive themselves as unsafe. Differences also occur in auditory LS in favour of safer drivers. Tactile and group LS are almost equally presented in both groups, while a slightly higher percentage of safer drivers prefer individual LS (Figure 4). The value axis in Figures 4 and 5 starts at 25\% since the minimum percentage of the respondents who have chosen any LS was never lower than 30\%, and also for aesthetic reasons.

Age and LS preferences. Major preferences of auditory and kinaesthetic LS are characteristic for younger drivers, up to the age of 21, while visual LS occupies the last place. Drivers over the age of 21 show major preferences for auditory and individual LS, with least preferences to kinaesthetic and group LS. Both groups preferred auditory LS in the same percentage. The

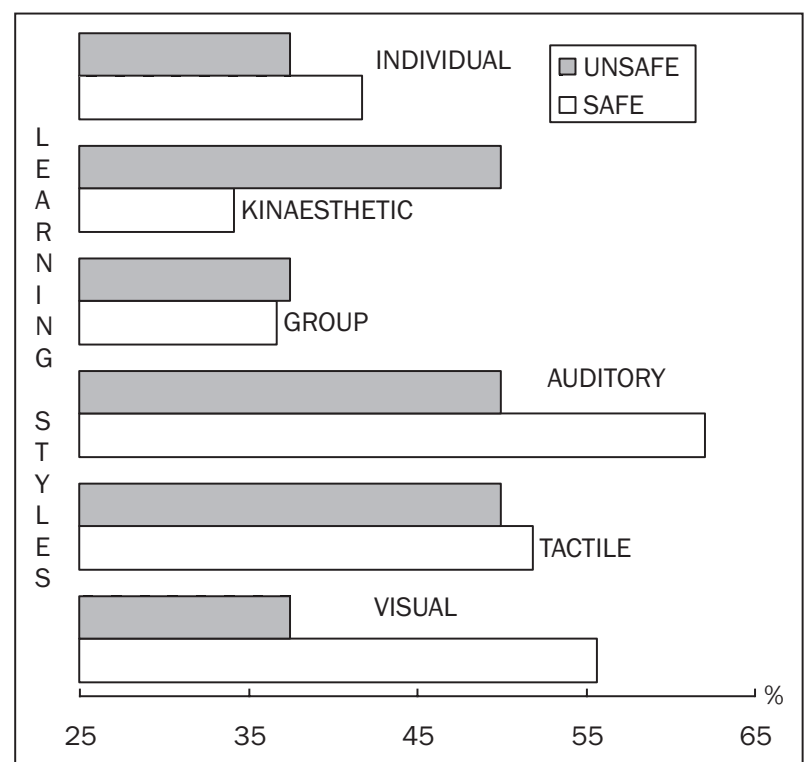

Figure 4 - Distribution of major learning style preferences with respect to self-assessment of safety

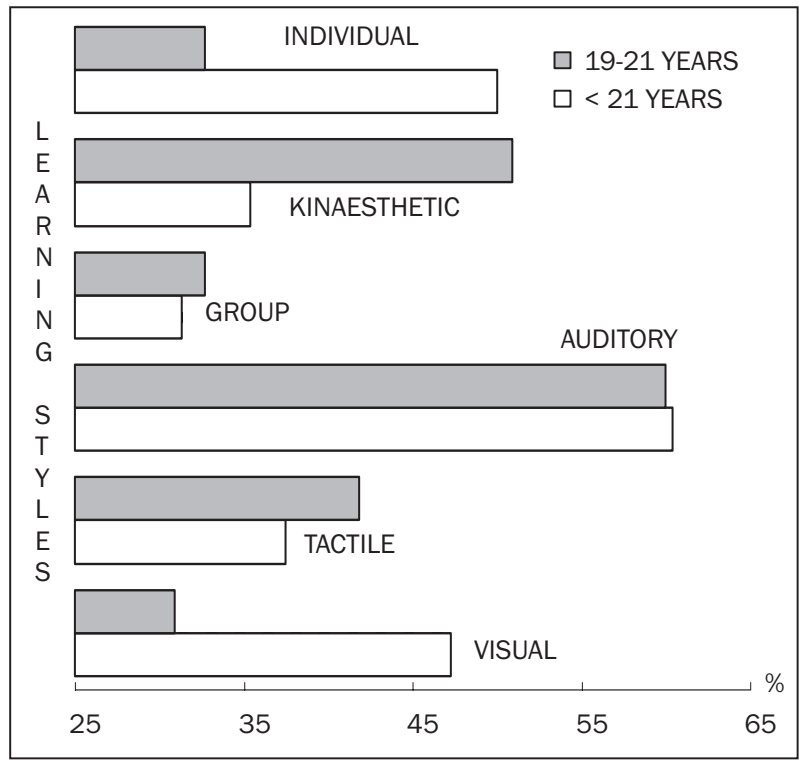

Figure 5 - Distribution of major learning style preferences with respect to age

biggest differences are manifested in individual and visual LS, which were more preferred by the older drivers, as well as for kinaesthetic LS preferred by a larger proportion of drivers younger than 21 years of age. In terms of preferences for other styles, there are no major differences in relation to drivers' age (Figure 5).

\section{DISCUSSION}

Except the auditory LS, which is the most favourable for all the participants in the study, the role of kinaesthetic LS is very interesting for non-drivers and drivers without traffic accidents. On the contrary, it becomes of less importance for drivers involved in traf- 
fic accidents. Group LS shows the opposite with the drivers with traffic accidents favouring group orientation. Does it mean that kinaesthetic LS is significant at initial levels of skill acquisition, and is then being neglected, while drivers cease to rely on kinaesthetic bodily information, which consequently leads to traffic accidents involvement? Thus, the emphasis in the re-education process should be on the better usage of such information. It is obvious that auditory is the dominant way of adopting knowledge and information processing for all participants in this study, and therefore, should be emphasized during training, but on the other hand, the importance of kinaesthetic modality for the driving task, as well as information feedback hereby given, has to be highlighted and should not be neglected. Sellen et al. [33] present experimental results which suggest that kinaesthetic feedback is a more salient modality than visual feedback in preventing mode errors. This demonstrates a situation in which kinaesthetic feedback can be important, even when visual feedback is simultaneously available, especially because kinaesthetic stimuli show more rapid processing and faster response time (RT) as compared to their combination with visual stimuli, which due to visual attention can lead to slower RT. More specifically, the execution of any single movement requires the presence of two traces; the perceptual trace, which represents a recognition mechanism allowing the control of the movement precision and the mnemonic trace, which refers to a recall mechanism permitting the selection and production of movement. For motion perception, the crucial information is given by the steering wheel force feedback, perceived by human muscular and musculo-articular receptors. This kinaesthetic feedback perhaps is most important when driving (and on simulator). The effects of training strategies on the acquisition of motor and cognitive skills have occupied a very privileged place of interest among the researchers. The results demonstrated that performance obtained by the mental imagery (visual or kinaesthetic) combined with physical practice group was, during the retention phase, equivalent to that produced by the specific physical practice group but significantly superior during the transfer of closed motor skills. Gender differences are more explicit among drivers, than in the general sample. Male drivers show auditory, while female drivers show kinaesthetic LS as the most prominent. Still, males are two times more involved in traffic accidents than females. On the other hand, drivers, and safe drivers (those without traffic accidents) approved to be very similar with respect to LS distribution. Safe drivers have less procured group LS. Yet, taking into account driving experience, we could see that the role of kinaesthetic LS is reduced, since individual LS become more important. Moreover, LS representation is more uniform in novice drivers in comparison with their more experienced counterparts.
An analysis of the driver's task and accidents has shown that adequate psychomotor skills and physiological functions are not sufficient for good and safe performance as a driver.

The objective is to formulate a conceptual model of driver training and education. The educator's identification of student LS preferences can guide the selection of appropriate instructional methods and materials to maximize learning. Knowledge of student LS profiles can be used to guide instructional organization for individuals or groups with the same style preferences, and might also enable material developers to produce means that both match students' LS and help them manipulate beneficial strategies.

Our results and recommendations are in agreement with the suggestions made by Mayhew [34]; Foss [35]; Keating [36] and Ferguson et al., [37] upon several potential improvements that may help to enhance the process of driver education. Those are: adoption of multi-stage driver education (teaching basic driving skills, and after some driving experience, teaching safe driving procedures and decision-making); update course contents to focus on young drivers risk factors; using effective teaching methods; match instruction to the skill levels and needs of individual drivers; and, finally, help novice drivers to make accurate assessments of aspects of their own competence, so that, although this is a great challenge, it would be highly beneficial for traffic safety.

We suggest that further empirical research is particularly needed employing other instruments for LS measurement which could catch other different LS dimensions; also on larger samples, for controls, as well as, for drivers involved in traffic accidents, with respect to number, type, and consequences of traffic accidents.

\section{CONCLUSION}

Based on the obtained results the following basic conclusions can be drawn:

1. Auditory is the most prominent LS in all groups;

2. Drivers in general, as well as drivers without traffic accidents favour visual and tactile LS;

3. The main difference between controls and drivers involved in traffic accidents occur in kinaesthetic LS preferences. Both, inexperienced and highly experienced drivers show relatively high preference of kinaesthetic LS;

4. Reducing the number of young, novice driver crashes and fatalities will require a focused and co-coordinated approach, involving education, training, licensing, enforcement, communication and the selective use of technology in combination with other road safety measures; 
5. The goals and the pedagogical methods should be carefully analyzed when safety effects of training are evaluated. What kinds of measures are effective in teaching those skills or is it possible to teach them at all. Do we have to support the learning process and how can we do it in an effective way? We may also have other questions concerning driver training and systematic and conceptually wellbased tools, to help us formulate the right questions and help us answer those in the future.

\section{ACKNOWLEDGMENT}

This study was supported by The Ministry of Science and Technological Development of Serbia (project 36022).

\section{Dr SVETLANA ČIČEVIĆ}

E-mail: s.cicevic@sf.bg.ac.rs

Dr VLADAN TUBIĆ

E-mail : vladan@sf.bg.ac.rs

Univerzitet u Beogradu, Saobraćajni fakultet

Vojvode Stepe 305, 11000 Beograd, Srbija

Dr MILKICA NEŠIĆ

E-mail : milkica@medfak.ni.ac.rs

Univerzitet u Nišu, Medicinski fakultet

Bulevar dr Zorana Đinđića 81, 18000 Niš, Srbija

Mr MARJANA ČUBRANIĆ-DOBRODOLAC

E-mail : marjana@sf.bg.ac.rs

Univerzitet u Beogradu, Saobraćajni fakultet

Vojvode Stepe 305, 11000 Beograd, Srbija

\section{REZIME}

\section{PREFERENCIJE PERCEPTIVNIH STILOVA UČENJA I SAOBRAĆAJNE NEZGODE MLADIH VOZAČA}

Povrede i fatalni ishodi saobraćajnih nezgoda vozača u uzrastnoj grupi od 15-29 godina predstavljaju ozbiljan problem za svako društvo. Jedan od načina rešavanja ovog problema je postizanje primarne prevencije kroz obrazovanje i obuku vozača. U ovom radu analizirani su faktori saobraćajnih nezgoda koji se tiču mladih vozača, a odnose se na: pol, uzrast, vozačko iskustvo, pređenu kilometražu, kao i samopercepciju bezbednosti. Rezultati istraživanja ukazuju na dominaciju auditornog stila učenja u svim grupama. Kinestetički i auditivni stil dominantni su u kontrolnoj grupi. Vozači preferiraju vizuelni i taktilni stil učenja. Kinestetičk stil preferira relativno veliki procenat neiskusnih vozača, sa iskustvom se ta preferencija smanjuje, da bi kod grupe sa najvećom pređenom kilometražom, opet porasla. Iz rezultata istraživanja proizilazi osnovnizaključak daje prilagođavanjem metoda obučavanja, nastavnih materijala i instrukcija stilovima učenja vozača moguće brže i lakše usvajanje neophodnih veština i znanja i stvaranje bezbednijih vozača.

\section{KLUČNE REČI}

mladi vozači, saobraćajne nezgode, preferencija perceptivnih stilova učenja, samopercepcija bezbednosti, vozačko iskustvo, edukacija vozača

\section{LITERATURE}

[1] Racioppi, F.; Eriksson, L.; Tingvall, C.; Villaveces, A.: Preventing road traffic injury: A Public health perspective for Europe. World Health Organization Europe. Copenhagen, 2004

[2] Groeger, J.A.; Brown, I.D.: Assessing one's own and others' driving ability: Influences of sex, age, and experience, Accident Analysis and Prevention, 21(2), 1989, 155-168

[3] Brorsson, B.; Rydgren, H.; Ifver, J.: Single-vehicle accidents in Sweden: A comparative study of risk and risk factors by age, Journal of Safety Research, 24(1), 1993, 55-65

[4] Lynam, D.; Twisk, D.: Car Driver Training and Licensing Systems in Europe, Report prepared by members of Forum of European Road Research Institutes (FERSI) and supported by European Commission Transport Directorate (DG VII), Report No. 147, 1995, Crowthorne (UK): Transport Research Laboratory (TRL)

[5] Clarke, D.D.; Ward, P.; Bartle, C.; Truman, W.: Young driver accidents in the UK: The influence of age, experience, and time of day, Accident Analysis and Prevention, 38(5), 2006, 871-878

[6] Gregersen, N.P.: Young drivers' overestimation of their own skill-an experiment on the relation between training strategy and skill, Accident Analysis and Prevention, 28(2), 1996, 243-250

[7] Matthews, M.L.; Moran, A.R.: Age differences in male drivers' perception of accident risk: The role of perceived driving ability, Accident Analysis and Prevention, 18(4), 1986, 299-313

[8] Gregersen, N.P.; Berg, H.Y. Lifestyle and accidents among young drivers, Accident Analysis and Prevention, 26(3), 1994, 297-303

[9] Deery, H.A.: Hazard and risk perception among young novice drivers, Journal of Safety Research, 30(4), 1999, 225-236

[10] Hatakka, M.; Keskinen, E.; Gregersen, N.P.; Glad, A.; Hernetkoski, K.: From control of the vehicle to personal self-control; broadening the perspectives to driver education, Transportation Research Part F, 5(3), 2002, 201-215

[11] Nätänen, R.; Summala, H.: A model for the role of motivational factors in drivers' decision-making, Accident Analysis and Prevention, 6(3-4), 1974, 243-261

[12] Spolander, K.: Drivers' assessment of their own driving ability. Report No. 252, Swedish Road \& Traffc Research Institute, Linköping, 1983

[13] Groeger, J.A.; Brady, S.J.: Differential effects of formal and informal driver training. Road Safety Research Report No. 42, 2004, Department for Transport, London

[14] Norwegian Public Roads Administration.: Driver training in Norway. Foundation for the revisions of the regulations and curricula 2005., Oslo, Norwegian Public Roads Administration, 2005

[15] McCormick, I.A.; Walkey, F.H.; Green, D.E.: Comparative perceptions of driver ability - A confirmation and expansion, Accident Analysis and Prevention, 18(3), 1986, 205-208

[16] Goszczynska, M.; Roslan, A.: Self-evaluation of drivers' skill: A cross-cultural comparison, Accident Analysis and Prevention, 21(3), 1989, 217-224 
[17] Delhomme, P.: Comparing one's driving with others': Assessment of abilities and frequency of ofences. Evidence for a superior conformity of self-bias? Accident Analysis and Prevention, 23(6), 1991, 493-508.

[18] Lajunen, T.; Summala, H.: Driving experience, personality, and skill and safety-motive dimensions in drivers' self-assessments, Personality and Individual Differences, 19(3), 1995, 307-318

[19] Sivak, M.; Soler, J.; Tränkle, U.: Cross-cultural differences in driver self-assessment, Accident Analysis and Prevention, 21(4), 1989, 371-375

[20] Kolb, D.A.: Experiential Learning: experience as the source of learning and development. New Jersey: Prentice-Hall, 1984.

[21] Mezirov, J.: A critical theory of adult learning and experience, Adult education, 32(1), 1981, 3-24

[22] Mezirow, J. (Ed.).: Fostering Critical Reflection in Adulthood: a guide to transformative and emancipatory learning, San Francisco: Jossey-Bass, 1990

[23] Kliukas, R.; Prentkovskis, O.; Daniūnas, A.: Qualitative analysis of the knowledge of applicants to transport engineering courses of study, Transport, 21(2), 2006, 95-104

[24] Sadauskas, V.: Investigation of road accidents on Lithuanian state roads, Transport, 21(4), 2006, 289292

[25] Nyberg, A.: The Potential of Driver Education to Reduce Traffic Crashes Involving Young Drivers. Linköping University Medical Dissertation No. 985, 2007

[26] Reid, J.M. (Ed.): Learning Styles in the ESL/EFL Classroom. New York: Heinle and Heinle Publishers, 1995

[27] Keefe, J.W.: Learning style: An overview. In NASSP's Student learning styles: Diagnosing and prescribing programs,1979, pp. 1-17, Reston, VA: National Association of Secondary School Principals

[28] Dunn, R. S.; Dunn, K.J.: Learning styles/teaching styles: Should they ... can they . . be matched? Educational Leadership, 36(4), 1979, 238-244

[29] Hyland, K.: Culture and learning: a study of the learning style preferences of Japanese students, RELC Journal, 24 (2), 1993, 69-91

[30] Decapua, A.; Wintergerst, A.C. Assessing and validating learning styles instrument, System, 33(1), 2005, 1-16

[31] Reid, J.M.: The learning style preferences of ESL students. TESOL Quarterly, 21(1), 1987, 87-111

[32] Dorsey, O.L., \& Pierson, M.J. (1984). A descriptive study of adult learning styles in a non-traditional education program. Lifelong Learning: An Omnibus of Practice and Research, 7, 8-11.

[33] Sellen, A.; Kurtenbach, G.; Buxton, W.: The prevention of mode errors through sensory feedback, Human Computer Interaction, 7(2), 1992, 141-164

[34] Mayhew, D.R.: Driver education and graduated licencing in North America: Past, present, and future, Journal of Safety Research, 38(2), 2007, 229-235

[35] Foss, R.: Improving graduated licencing systems: Implement principles rather than laws, Journal of Safety Research, 38(2), 2007, 185-192

[36] Keating, D.: Understanding adolescent development: Implications for driving safety, Journal of Safety Research, 38(2), 2007, 147-157

[37] Ferguson, S.A.; Teoh, E.R.; McCartt, A.T.: Progress in teenage crash risk during the last decade, Journal of Safety Research, 38(2), 2007, 137-145 